\title{
Nilai dalam Pendidikan Seks bagi Anak Usia Dini
}

\author{
Ratih Rahmawati \\ IAIN Metro \\ Email: ratihra7@gmail.com
}

\begin{abstract}
This study was aimed to analyze the values and sex education for children. Values in sex education is very important. Including the values such as values of family and loving family ever teachers in schools. The children needs to get the true answers from adults, parents and teachers. The role of them are to guide, to take care, to teach, etc. Sex education it is not only to explain the sexuality of human being about biology or social but also to give the wide insight about sexuality within values. The purpose is prevent the body from sexual abuse. Moreover, help the children to construct that sexuality stay in values.
\end{abstract}

Keywords: childrens; sex educatio, values

\begin{abstract}
Abstrak
Penelitian ini bertujuan untuk menganalisis nilai-nilai dan pendidikan seks untuk anakanak. Nilai-nilai dalam pendidikan seks sangat penting. Termasuk nilai-nilai keluarga, kasih sayang keluarga bahkan guru-guru di sekolah. Anak-anak perlu mendapatkan jawaban yang benar dari orang dewasa, orang tua, dan guru. Peran mereka adalah membimbing, merawat, mengajar dan lain-lain. pendidikan seks tidak hanya menjalaskan seksualitas manusia tentang Biologi atau Sosial tetapi juga untuk memberikan wawasan luas tentang seksualitas dalam nilai-nilai. Tujuannya adalah mencegah tubuh dari pelecehan seksual. Selain itu, membantu anak-anak membangun bahwa seksualitas itu tetap bernilai.
\end{abstract}

Kata Kunci: anak-anak; pendidikan seks; nilai-nilai; 


\section{PENDAHULUAN}

Setiap ilmu memiliki metode pengembangan. Metode pengembangan PAUD didasarkan atas pengamatan dan penelitian. Para guru, praktisi, peneliti, dan orang tua senantiasa mengamati perkembangan anak. Hasil perkembangan tersebut merupakan masukan yang sangat berguna dalam membangun ilmu PAUD.

Banyak orang tua bahkan di lingkungan pendidikan sekalipun, yang akan merasa tidak nyaman ketika mendengar istilah "sex education" atau pendidikan seks. Apalagi pendidikan seks yang diajarkan untuk anak usia dini. Hal ini diawali dari pengertian yang salah kaprah tentang makna dari pendidikan seks itu sendiri. Orang tua maupun guru terkadang merasa tidak nyaman atau menganggap tabu ketika harus menjelaskan tentang hal-hal terkait dengan pendidikan seks. Tidak sedikit orang tua yang tidak bisa menjawab ketika anaknya bertanya dari mana asalnya adik bayi. Guru pun demikian tidk segera menjawab pertanyaan tersebut bahkan terkadang segera mengalihkan pembicaraan atau pertanyaan anak ketika itu berkaitan dengan organ reproduksi.

Pendidikan seks dimaksudkan untuk anak adalah pendidikan bagaimana anak dapat mengenal jenis kelaminnya, bagaimana anak dapat melindungi dirinya sendiri, dan yang lebih penting bagaimana anak dapat belajar untuk menjaga kebersihan anggota tubuh, merawat anggota tubuh seperti organ reproduksi serta dapat terbuka dan bercerita kepada orang tua ketika anak dapat perlakuan yang tidak baik. Pendidikan seks untuk anak dapat dimulai dari mengenalkan anak pada apa itu seks bukan pada hubungan seks. Yaitu lebih kepada jenis kelamin, yang membedakan antara laki-laki dan perempuan secara biologis, untuk anak-anak lebih mudah dikenalkan dengan sebutan putra dan putri.

Pengajaran pada anak tentu saja harus dilakukan secara kompak, antara ayah, ibu, dan anggota keluarga yang tinggal serumah, sehingga anak akan memperoleh jawaban yang sama. Pengajaran juga harus dengan bahasa dan analogi yang mudah dimengerti oleh anak. Anak-anak perlu dikenalkan tentang bagianbagian tubuhnya misalnya mandi, termasuk organ reproduksinya sambil berdialog dan menjelaskan fungsinya. Misal ketika sedang menyabun orang tua bisa bercerita bagian mana saja yang tidak boleh dipegang oleh orang lain, anggota tubuh mana yang harus dilindungi dan jika disentuh orang lain harus segera bilang kepada orang tua, sekali lagi dengan bahasa yang dapat dimengerti anak.

Berdasarkan pada hal tersebut, kajian ini akan membahas dan menganalisa lebih dalam bagaimana orang tua ataupun guru menanggapi dengan tepat 
pertanyaan-pertanyaan anak tentang seks. Sebagai orang tua sudah seharusnya memberikan jawaban yang tepat dan memuaskan pemahaman mereka dengan kadar sesuai dengan usia mereka sehingga mampu mencegah terjadinya pemahaman yang salah bagi anak untuk masa mendatang. Anak-anak adalah aset besar yang berhak mendapatkan pengawasan dan perawatan yang tepat khususnya tentang pendidikan seks sejak dini. Orang tua harus berusaha mampu memberikan penjelasan yang mengandung nilai-nilai positif bagi anak.

\section{METODOLOGI}

Penelitian ini merupakan penelitian kualitatif yang merupakan metode penelitian yang berlandaskan pada filsafat postpositivisme. Dalam penelitian kualitatif, penelitian ini mencoba mengkaji beberapa sumber data tentang pendidikan seks anak usia dini.

Pengumpulan data diperoleh dari sumber kepustakaan. Dengan kata lain, penelitian ini merupakan studi pustaka tentang bagaimana pendidikan seks dapat menumbuhkan nilai nilai bagi anak usia dini; bagaimana pendidikan seks bagi anak juga memunculkan nilai-nilai positif bagi anak.

\section{HASIL DAN PEMBAHASAN}

\section{Pendidikan Seks}

Pendidikan seks lebih dari sekedar kajian tentang seksualitas manusia dalam pelajaran biologi atau ilmu sosial. Tujuan mempelajari seksualitas manusia adalah agar siswa mengetahui lebih banyak tentang seks dan tujuan pendidikan seks terhampar di balik ini, termasuk mendorong semacam keterampilan atau kecakapan, sikap, kecenderungan, perilaku dan refleksi kritis terhadap pengalaman pribadi. Cara lain mengekspresikan untuk mengatakan bahwa pendidikan seks harus mendidik dan pendidikan adalah aktivitas yang sarat dengan nilai.

Seks dalam arti yang sempit bararti kelamin, seks dalam arti yang luas berarti seksualitas. Seksualitas merupakan sesuatu yang berkaitan dengan seks. Pendidikan seks adalah upaya pengajaran, penyadaran dan pemberian informasi yang diberikan di antaranya pengetahuan tentang fungsi organ reproduksi dengan menanamkan moral, etika, komitmen, agama, agar tidak terjadi "penyalahgunaan " organ reproduksi tersebut. Penanaman nilai-nilai agama adalah salah satu aspek pengembangan anak usia dini yang menjadi tanggung jawab pendidikan. (Solihin 
2015). Itulah mengapa pendidikan seks dapat dilakukan sebagai cikal bakal pendidikan kehidupan berkeluarga yang memiliki makna sangat penting.

Pendidikan seks diartikan sebagai anatomi organ tubuh yang dapat dilanjutkan pada reproduksi seksualnya dan akibatnya bila dilakukan tanpa mematuhi aturan hukum, agama, dan adat-istiadat, serta kesiapan mental.

Pendidikan seks anak usia dini, menurut Rose Mini pengetahuan seksualitas wajib diberikan ke anak sejak usia 3-4 tahun. Anak-anak perlu diajarkan tentang persamaan dan perbedaan antara pribadi seorang anak laki-laki dan perempuan. Tujuannya agar anak mampu mengenali diri mereka dengan baik. Meskipun demikian, dalam menyampaikan perlu memperhatikan dan menyesuaikan kesiapan psikologi anak. Langkah awal yang dapat dilakukan adalah mengajari dan membiasakan anak agar membiasakan diri membersihkan alat kelaminnya sendiri setelah buang air kecil atau besar. Ini bertujuan agar anak tidak bergantung pada orang lain. Penanaman sikap mandiri akan memberikan pengajaran pada anak tentang etika.

Pendidikan seks adalah upaya pengajaran, penyadaran, dan penerangan tentang masalah-masalah seksual yang diberikan pada anak, dalam usaha menjaga anak terbebas dari kebiasaan yang tidak Islami serta menutup segala kemungkinan ke arah penyimpangan seksual.

Maraknya kasus penyimpangan seksual yang terjadi akhir-akhir ini tidak lagi hanya mengancam remaja yang rentan terhadap informasi yang salah mengenai seks. Ini merupakan bukti nyata kurangnya pengetahuan anak mengenai pendidikan seks yang seharusnya sudah mereka sudah peroleh dari tahun pertama oleh orang tuanya.

Pada usia anak dini, pendidikan seks dapat diberikan untuk menjelaskan hal-hal yang menjelaskan tentang fungsi alat kelamin laki-laki dan perempuan serta menjaga diri sendiri dari orang-orang yang berniat buruk melakukan kekerasan seksual. Perkembangan Psikoseksual, menurut Hastomo mengungkapkan bahwa secara umum pengalaman seksualitas pada anak usia dini lebih menekankan pada perilaku atau kebiasaan. Sedangkan fungsi seksualnya belum mengalami perkembangan yang signifikan.

Menurut Ratnasari, memberikan bekal pengetahuan tentang seks, mereka menjadi mengerti perilaku mana yang tergolong pelecehan seksuan ataupun bukan. 
Sehingga pendidikan seks juga dapat mencegah anak agar tidak menjadi korban pelecehan seksual. (Ratnasari and Alias 2016)

Dan untuk menekankan pada perilaku atau kebiasaan anak, lingkungan di sekitar anak usia dini memiliki peran penting. Ini juga merupakan bentuk pencegahan kekerasan seksual yang dapat terjadi. Salah satunya membekali anak pengetahuan, nilai-nilai, sikap, dan keterampilan yang berhubungan dengan anatomi tubuh, hubungan personal, dan seksualitas, memberikan pendidikan seksualitas atau memberikan pendidikan seksual pada anak usia dini. Peran ini salah satunya dapat dipenuhi oleh guru di sekolah karena sekolah merupakan institusi formal profesional yang bisa memberikan pendidikan seksual secara terstruktur dan anak menghabiskan sebagian waktunya di sekolah.

Sekolah juga merupakan tempat anak bersosialisasi dan berinteraksi dengan orang dewasa lain yang bukan keluarganya sehingga memiliki banyak contoh nyata dalam belajar pendidikan seksual.

Setiap anak juga memiliki latar belakang keluarga yang berbeda. Ada yang memiliki orang tua yang sudah paham pendidikan seksual, ada pula yang belum paham. Jadi, keterbatasan orang tua dalam memberikaan pendidikan seksual bagi anak-anak karena tidak semua anak berasal dari keluarga dengan pola komunikasi atau interaksi yang hangat dan terbuka untuk membahas seksualitas.

Dibalik keterbatasan tersebut, ternyata banyak orang tua yang sadar untuk memasukkan anak-anaknya ke PAUD sehingga peran guru PAUD menjadi penting dalam mewadahi pendidikan seksual bagi anak.

Kemampuan dan minat anak pada perkembangan usia 4-6 tahun mengalami banyak perubahan yang sangat berarti, sehingga banyak hal yang layak untuk diberikan pada usia tersebut. Pada kondisi yang normal, umumnya anak usia ini sudah memiliki kematangan pada seluruh kemampuan. Banyak hal yang menakjubkan seolah terjadi membuat orang dewasa bangga dan senang tetapi juga terkadang melakukan aktivitas di luar kontrol diri berakibat membahayakan dirinya dan orang lain. anak usia ini senang melakukan berbagai eksplorasi terhadap segala sesuatu yang dilihat, didengar maupun yang dapat dirasakannya sebagai wujud dari keingintahuannya begitu besar.

Berkaitan dengan rasa keingintahuan anak-anak yang sangat tinggi. Bahkan muncul beberapa pertanyaan yang terkadang membuat orang tua atau guru sulit untuk menjelaskan. Sebagai contoh, dari mana datangnya adik bayi?; kenapa ibu 
mengandung? Kenapa bagian bentuk tubuh berbeda punya anak laki-laki dan perempuan? Rasa ingin tahu pada anak, sikap yang dibentuk anak terhadap anggota tubuh dan fungsi-fungsinya merupakan unsur-unsur penting dalam pendidikan seks tahap dini, misalnya mereka tertarik kepada gerakan-gerakan kaki, tangannya, jari tangannya dan bagian tubuh yang mengundang perhatian. Pengenalan anatomi ini adalah peran bagi orang tua.

Pengenalan anatomi tubuh ini dapat dapat dilakukan oleh orang tua. Pengajaran pada anak tentu saja harus dilakukan secara kompak, antara ayah, ibu, dan anggota keluarga yang tinggal serumah, sehingga anak akan memperoleh jawaban yang sama. Pengajaran juga harus dengan bahasa dan analogi yang mudah dimengerti oleh anak.

Anak-anak perlu dikenalkan tentang bagian-bagian tubuhnya misalnya mandi, termasuk organ reproduksinya sambil berdialog dan menjelaskan fungsinya. Misal ketika sedang menyabun, orang tua bisa bercerita bagian mana saja yang tidak boleh dipegang oleh orang lain, anggota tubuh mana yang harus dilindungi dan jika disentuh orang lain harus segera bilang kepada orang tua, sekali lagi dengan bahasa yang dapat dimengerti anak. Ini sebagai satu contoh memberikan wawasan anak di rumah. Orang tua seharusnya pandai memanfaatkan waktu yang tepat untuk menjelaskan kepada anak.

Dan dapat pula dilakukan oleh orang tua atau guru dengan menggunakan media boneka. Ketika di sekolah guru dapat mempraktikkan cara memandikan dan memakaikan baju pada boneka tersebut di saat kegiatan bermain peran. Anak dapat dikenalkan tentang pentingnya pakaian yang sopan, misal anak perempuan dapat pula dibiasakan memakai pakaian yang tertutup ketika keluar rumah.

Orang tua dan guru dapat mengenalkan tentang perbedaan laki-laki dan perempuan dimulai dari cara berpakaian, kemudian dapat pula dijelaskan peran jenis kelamin, seperti ibu melahirkan, ayah bekerja. Anak adalah peniru ulung. Karena sifat penirunya inilah anak membutuhkan model atau teladan. Model dan teladan terbaik adalah orang tua.

\section{Tujuan dan Perkembangan Nilai Pendidikan Seks bagi Anak}

Tujuan pendidikan seks sesuai usia perkembangan pun berbeda-beda. Seperti pada usia balita, tujuannya adalah memperkenalkan organ seks yang dimiliki, seperti menjelaskan anggota tubuh lainnya, termasuk menjaga fungsi serta cara 
melindunginya. Jika tidak dilakukan sejak awal kemungkinan anak akan mendapatkan banyak masalah seperti memiliki kebiasaan memegang alat kemaluan sebelum tidur, suka memegang payudara orang lainatau masalah lainnya.

Masalah-masalah tersebut sudah harus kita cegah, karena bila ini sudah menyentuh nilai. Mereka harus, wajib mendapatkan pendidikan seks yang bernilai (value).

Untuk usia 6-10 tahun bertujuan memahami perbedaan jenis kelamin laki-laki dan perempuan, menginformasikan asal-usul manusia, membersihkan alat genital dengan benar agar terhindar dari kuman dan penyakit. Sedangkan usia remaja, pendidikan seks bertujuan untuk menerangkan masa pubertas dan karakteristiknya, serta menerima perubahan dari bentuk tubuh.

Pendidikan seks berguna untuk memberi penjelasan mengenai perilaku seks merugikan seperti seks bebas, menanamkan moral dan prinsip "say no" untuk seks pranikah serta membangun penerimaan terhadap diri sendiri, bahkan pendidikan seks juga penting diberikan kepada pasangan yang ingin menikah tentang hubungan seks yang sehat dan tepat. Demikian gambaran tentang tahapan pendidikan seks dan betapa pentingnya agar bisa tepat diinformasikan kepada objek dengan tepat sasaran sesuai peran dan tujuannya yakni menumbuhkan nilai dalam pendidikan seks pada tiap pribadi anak, remaja maupun orang tua anak.

Kembali pada kupasan salah satu tujuan pentingnya pendidikan seks pada anak usia dini adalah menjaga kesehatan tubuhnya dari orang-orang yang berniat buruk pada anak. Perkembangan Nilai dalam Pendidikan Seks. Ada kaitan erat antara nilai yang mendasari konseptualisasi, rencana dan implementsi pendidikan seks dan nilai yang diajarkan pada siswa dalam pendidikan seks.

Proses pendidikan seks sarat nilai adalah mungkin secara teori (value-laden), tetapi nilai seharusnya termasuk bagian dari isi pendidikan seks. Siswa di sekolah tidak hanya belajar apa yang diajarkan, tetapi juga mengambil sesuatu melalui proses dari kurikulum yang tidak langsung (hidden). Dan jika pendidikan seks dipenuhi (saturated) nilai sebagaimana kita inginkan, tidak ada alasan untuk menghentikan siswa mengambil beberapa nilai tersebut sekalipun tanpa memiliki tanggung jawab moral untuk mengetahui, atau mengenal cara mereka mempengaruhi pertumbuhan atau perkembangan nilai anak-anak dan membawa pengaruh ini pada kesadaran.

Pada sisi ini memungkinkan refleksi hati-hati atau mendalam terhadap pengaruh yang mereka miliki dalam perkembangan nilai dengan tujuan meyakinkan bahwa pengaruh ini masuk akal, bisa dijustifikasikan dan sangat menarik bagi anak-anak 
yang mereka ajar. Sadar atau tidak, seseorang dipaksa menyimpulkan bahwa pendidikan moral (lebih luasnya pendidikan nilai), tidak bisa lepas dari pendidikan seks. Begitu pula sebaliknya, pendidikan seks harus disertakan nilai sejak dini, agar anak mengerti dan menghargai ilmu tentang seks. Tanamkan pada mereka bahwa seks adalah hal alamiah.

Berhubungan dengan pendidikan moral terhadap seks anak usia dini maupun sebaliknya, tentunya harus memperhatikan rentang tahapan atau usia anak. Pertama, pada usia 3-4 tahun, jangan ragu untuk memperkenalkan alat kelamin si kecil. Saat yang paling tepat untuk mengajarkannya adalah di saat sedang memandikannya. Diharapakan agar menyebut alat kelamin sesuai namanya. Misalnya vagina atau penis, jangan diistilahkan "apem" atau "burung". Dan tidak perlu pula membahasnya terlalu detail mengenai alat kelamin anak anda dalam kondisi belajar yang serius. Kenapa demikian, karena apabila anak diberikan penjelasan dengan istilah "apem" atau "burung", maka justru akan menimbulkan kesan yang keliru. Mereka akan beranggapan bahwa kelamin yang mereka miliki seperti nama makanan atau nama hewan, yang ini berpotensi memicu pikiran mereka bahwa alat tersebut tidak vital, tidak begitu penting. Hanyalah sebuah makanan atau bahkan mainan. Kalau sampai bertambahnya usia mereka dan tidak segera diberikan pemahaman yang benar dan santun mereka akan menjadikannya sebagai celotehan-celotehan atau gurauan dengan kawan-kawan sebayanya. Jadi kepada orang tua agar dapat menjelaskan kepada anak dengan sebaik-baiknya dan apa adanya dengan ajaran yang bijak.

Ajarkan kepada anak bahwa seluruh tubuhnya, termasuk alat kelaminnya adalah milik pribadinya yang harus dijaga baik-baik. Ajarkan agar mereka tidak menunjukkan kelaminnya secara sembarangan. Jelaskan kepada mereka bahwa mereka memiliki hak dan bisa menolak segala macam bentuk kasih sayang melalui sentuhan fisik. Hal ini menjadi penting karena disukai atau tidak, banyak pelaku pelecehan seksual adlaah orang-orang yang dekat dengan kehidupan si anak. Orang tua juga tidak boleh memaksa seorang anak untuk memeluk atau mencium orang lain jika dia tidak menginginkan maka si anak bisa belajar untuk menyatakan penolakan. Lebih baiknya lagi kalau orang tua melakukan pencegahan atau penjagaan ekstra bagi anak. Kecuali bagi orang tua yang super ibuk dengan karirnya, maka dapat mencari asisten terpercaya untuk penjagaan aman bagi anak-anak mereka.

Selanjutnya, untuk anak usia 6-9 tahun. Anak usia ini diajarkan mengenai apa saja yang harus dilakukan untuk melindungi dirinya sendiri. orang tua harus memperhatikan suasana hati anak agar saat menyampaikan materi seksualitas, anak 
tidak merasa terpojokkan, malu, bodoh, atau terlalu liar dalam menyikapi seks. Hindari kata-kata yang menghakimi anak saat membicarakan pengalaman seksual mereka. Jika orang tua merasa agak benar membahas topik seksual anak, orang tua bisa meminta bantuan psikolog atau konselor untuk memberikan pendidikan seksual kepada anak. Misalnya pun tidak mampu mendatangkan seorang psikolog, maka orang tua bisa belajar pengelaman dari siapapun yang sudah berpengalaman, bisa tetangga atau orang-orang yang mempunyai pengalaman luas tentang hal ini. jika tidak bisa dengan cara ini, maka manfaat internet dunia masa kini sudah sangat mudah. Orang tua bisa belajar dari sosial media yang saat ini amat mudah untuk bisa diakses. Sehingga dapa dengan mudah menemukan tutorial, atau artikel tentang tipstips, solusi bagaimana mengajarkan pendidikan seks pada anak dengan baik dan mudah.

Ada beberapa tips cerdas berbicara seks pada anak:

1) Luangkan waktu untuk membuat dialog atau diskusi tentang seks dengan anak. Orang tua harus menyediakan waktu, ia mampu memanajemen waktunya, kualitas waktu bagi anak. Kasih sayang nya tidak hanya berupa materi, tapi juga kebutuhan psikis anak dan ajaran-ajaran fundamental dari orang tua anak, khususnya seperti pendidikan tentang seks ini.

2) Sikap terbuka, informatif, dan yakin. Orang tua harus mampu memberikan penjelasan dengan terang, bermakna dan mampu meyakinkan anak. Sehingga anak dapat yakinn memahami apa yang telah diajarkan kepadanya.

3) Siapkan materi dan penyampaian disesuaikan dengan usia anak. Bahasa yang digunakan untuk menjelaskan materi tentang seks harus sesuai dengan tingkat kemampuan anak, usia anak.

4) Gunakan media atau alat bantu konkret seperti boneka, gambar, binatang untuk memudahkan anak menyerap informasi. Hal ini untuk menyesuaikan bahwa anak masih dalam tahapan pemikiran yang konkret. Mereka akan mudah mengerti dengan contoh-contoh nyata yang dapat mereka lihat dengan jelas.

5) Membekali diri dengan wawasan cukup untuk menjawab pertanyaan anak. Sebelum menjelaskan kepada anak ornag tua dituntut untuk mempersiapkan wawasan seluas-luasnya. Agar anak memahami secara utuh tentang kuriositasnya.

6) Menjawab pertanyaan dengan jujur dan dengan bahasa yang lebih halus. Jawaban yang jujur dan halus merupakan bentuk pendidikan seks dengan memasukkan nilai-nilai moral. Hal ini dapat membuat anak dengan tenang memahami dan meneladani sikap-sikap positif terhadap penjelasan dan sikap orang 
tuanya. Pada usia tertentu anak-anak memasuki lingkungan sosial baru yang lebih luas. Mereka akan mengembangkan minat dan mengkonstruksi identitas diri dan pemahaman nilai-nilai yang menghubungkan anak dengan lingkungannya. (Ruíz 2015)

7) Dalam memberikan pendidikan seks pada anak sebaiknya anak mengenali bagian tubuh dirinya sendiri dan jangan pernah mengeksplor tubuh orang lain. dalam hal ini sudah tentu seorang anak memiliki sikap melindungi diri, melindungi fisik mereka dari orang lain. dengan demikian anak juga dilarang untuk tidak mengeksplor milik orang lain.

8) Mendiskusikan kepada ahli atau psikolog apabila ada hal-hal yang masih ragu atau bingung dalam memberikan informasi. Ini merupakan salah satu cara bagi orang tua yang kewalahan, atau tidak mampu menangani sendiri memberika ajaran bagi anaknya.

9) Meyakinkan diri bahwa pendidikan seks pada anak adalah penting dan bermanfaat.

Berikut ini sebagai salah satu contoh teknik pendidikan seks, sebagaimana pendidikan dengan materi apapun harus disesuaikan dengan tujuan, tingkat kedalaman materi, usia anak, tingkat pengetahuan dan kedewasaan anak, dan media yang dimiliki oleh pendidik. Penjelasan harus dikemas dalam tradisi lokal yang positif, moral, dan ajaran agama. Misalnya, anak yang berasal dari keluarga suku jawa dan berada di lingkungan yang mayoritas jawa. Hubungan seks dalam pandangan jawa merupakan sesuatu yang luhur, sakral, dan memiliki fungsi untuk menjaga keharmonisan dan kelangsungan hidup manusia.

Secara edukatif, anak bisa diberi pendidikan seks sejak ia bertanya di seputar seks. Bisa jadi pertanyaan anak tidak terucap lewat kata-kata, untuk itu ekspresi anak harus bisa ditangkap oleh orang tua atau pendidik.

\section{Seksualitas Anak, Mengkonstruksi Bentuk Nilai}

Penelitian menunjukkan bahwa anak-anak adalah makhluk seksual. Mereka sangat tertarik dengan materi seksual, karena pesan konfliktif dari orang dewasa: pada satu sisi, pada satu sisi, anak tidak bisa lari dari image seksual yang dimasukkan pada mereka dari seluruh media. Namun di sisi lain, beberapa orang dewasa justru merahasiakan dan menyamarkan seks. Sikap mendua ini menambah keingintahuan anak-anak yang polos, yang menyebabkan seks menguasai sebagian besar porsi 
utama pikiran mereka dan banyak percakapan, aktifitas dan permainan mereka. Pendidikan seks tidak bisa mengabaikan pertumbuhan kepekaan seksual dan seksualisasi anak-anak.

Pendidikan seks bukan hanya mempelajari tentang aspek biologi atau sosial tetapi menyangkut masalah psikologis, budaya, moral, etika dan hukum. Tujuan utama pendidikan seks tidak hanya memberikan informasi tentang seksualitas tetapi juga menumbuhkan sikap, perilaku positif, dan refleksi kritis terhadap pengalaman individu. Tujuan lain dari pendidikan seks tidak hanya mencegah dampak negatif dari perilaku seks di usia dini. Di indonesia banyak anak-anak tidak mendapatkan pendidikan seks yang benar dan cukup. Mereka justru mendapat informasi tentang seks dari teman, internet yang tidak dapat dipertanggung jawabkan. Masalah kejahatan seksualyang menimpa anak, karena anak tidak memiliki bekal pengetahuan yang bisa membuat anak mengantisipasi berbagai kemungkinanperlakuan buruk masalah seks. Tanpa pengetahuan yang memadai, anak dengan mudah dijadikan korban oleh oknum-oknum jahat. Karena itulah, sangatlah penting anak-anak mendapat bekal memadai. Pendidkan seksual bukan hanya mengantisipasi anak menjadi korban kejahatan seksual tetapi juga mencegah anak menjadi pelaku dari kejahatan disebabkan adanya kelainan seksual.

Selain itu kecenderungan mereka kepada fasilitas teknologi informasi sehingga mempengaruhi perilaku mereka. (Roqib 1970)

Di setiap kasus, pendidikan seks dapat membantu mereka mengkonstruksi bentuk nilai bagi mereka sendiri, keluar dari perbedaan perspektif yang mereka jumpai. Terutama akan sangat membantu jika pendidikan seks memasukkan pendidikan emosi dan menawarkan kesempatan pada anak merefleksikan tentang kemurnian cinta, termasuk cinta seksual, keintiman dan hasrat. Juga dapat memasukkan eksplorasi bagian yang dimainkan oleh seks dalam perkembangan diri dan sejumlah pilihan terbuka bagi siapapun. Atau dapat memasukkan kesempatan bagi anak-anak untuk merefleksikan nilai-nilai diri seperti rasa tanggung jawab, menghargai, kesetiaan, kepekaan terhadap orang lain, pemaaf, integritas pribadi dan komitmen, khususnya pada konteks hubungan, kedekatan dengan keluarga.

Dampak pendidikan seks. Pendidikan seks yang kita dukung, tidak dapat berjalan dengan perbedaan nilai dari seluruh proyek pendidikan. Aktifitas moral penting terlibat dengan perkembangan semua orang yang seimbang, dengan perkembangan sikap khusus, keterampilan, watak, dan kualitas pribadi. 
Nilai-nilai keluarga. Problematika pengajaran nilai-nilai keluarga. Relasi antara pendidikan seks dengan keluarga sangat erat dan penting. Di satu sisi, keluarga adalah pemberi pendidikan seks pertama bagi anak remaja serta memiliki pengaruh terkuat (di samping teman sebaya dan media) dalam mengembangkan nilai-nilai seksual dan pemahaman seks anak-anak dan remaja. Dengan kata lain, keluarga adalah bagian yang tak terelakkan dalam pendidikan seks. Topik-topik seperti hubungan kekeluargaan, pengasuhan, perencanaan keluarga, adalah unsur-unsur yang pasti ada dalam berbagai program pendidikan seks. Sesungguhnya, salah satu tujuan pokok pendidikan seks adalah untuk mempersiapkan anak-anak memasuki kehidupan keluarga sebagai orang-orang dewasa.

Semua itu sudah jelas dan bukan persoalan yang masih kontroversial. Yang masih kontroversial justru masalah pengajaran nilai-nilai keluarga. Instilah nilai-nilai keluarga masih membingungkan. Dalam sebuah survey nasional di Australia, responden mengasosiasikan nilai-nilai keluarga dengan sekelompok nilai yang sangat konservatif, seperti menghormati orang tua, menikah dengan orang yang sama untuk hidup, menghargai otoritas.

Di Inggris, istilah nilai-nilai keluarga dihubungkan dengan tekanan dari pemerintah pusat, baru-baru ini agar menambah dimensi moral secara lebih eksplisit lagi ke dalam pengajaran nilai-nilai keluarga dalam pendidikan seks, dengan didasarkan atas pandangan tradisional yang cukup sempit mengenai keluarga.

Pendidikan seks, di manapun juga, sangat tidak selaras dengan pikiran anak muda, sebagaimana juga pendidikan seks dalam topik tentang cinta. Cinta adalah emosi yang penuh kekuatan dalam kehidupan banyak anak muda. Cinta adalah alasan terkuat mengapa masyarakat menikah. Cinta sangat menonjol dalam diskusi anak-anak mengenai hubungan-hubungan, dan secara mendasar tampak dalam pandangannya. Tetapi cinta hanya mendapat sedikit perhatian dalam panduanpanduan dari pemerintah, baik itu dalam hal seks dan pendidikan relasi maupun dalam pendidikan kesehatan pribadi dan masyarakat. Beberapa upaya telah dilakukan dalam memasukkan cinta sebagai nilai-nilai utama ke dalam mainstream pendidikan seks. Misalnya, dalam menggunakan frase seperti segera sesudah mereka (anakanak) cukup dewasa untuk berkeinginan memiliki relasi seksual tampak menggunakan perhitungan yang tak memadai mengenai cinta sebagai faktor yang memotivasi pengalaman seksual anak muda untuk pertama kalinya. 
Pendidikan seks tidak berarti sekedar menerangkan kepada anak sejumlah data yang berhubungan dengan proses berketurunan dan hubungan jasmani antara pria dan wanita, akan tetapi ia meliputi berbagai unsur yang cukup banyak, di antara sikap, perasaan, idola, kebiasaan keluarga sehari-hari dan berbagai informasi. Sikap dan perasaan merupakan unsur-unsur penting secara khusus. Apabila sikap orang tua dan guru terhadap masalah seks. Misalnya ada orang tua yang kehidupan seksual mereka baik atau sehat, akan tetapi mereka gagal dalam membekali anak-anak mereka dengan informasi yang cukup tentang pertumbuhan seks, dan soal keturunan, akan tetapi dapat dipastikan bahwa sikap anak-anaknya terhadap soalsoal seks pada umumnya sehat dan wajar. Kendatipun demikian hal itu tidak berarti bahwa informasi tidak berguna.

Dan juga perasaan orang dewasa penting, karena perasaan anak terhadap masalah-masalah seks dan penyesuaian diri terhadapnya sangat tergantung kepada pertumbuhan kepribadiannya dan penyesuaian emosinya. Maka anak yang tenteram dan disayang pada umumnya mempunyai sikap yang sehat terhadap masalah seks. Kendatipun kadang-kadang ia sering ingin tahu atau mencoba beberapa keadaan, namun rasa amannya mendorongnya untuk menghargai orang lain. dan juga dapat membantunya dalam melalui tahap-tahap pancaroba dalam perjalanan hidupnya menuju kehidupan dewasa dengan perilaku dan sikap tertentu. Maka pendidikan seks adalah hal penting dan tidak boleh dilupakan, dan si anak ada kalanya mendapat pendidikan seks dengan baik dan ada kalanya tidak. Sekedar menolak untuk membicarakan masalah seks sudah mengajarnya sesuatu, yaitu masalah-masalah tersebut patut dibicarakan dengan orang dewasa.

Hal-hal yang hendak dicapai dalam pendidikan seks:

Pertama, membantu anak-anak untuk merasakan bahwa seluruh anggota jasmaninya dan semua tahap-tahap pertumbuhan adalah sesuatu yang disukai dan mempunyai tujuan tertentu. Kedua, menjadikan si anak mengerti dengan jelas tentang proses berketurunan, karena ia seharusnya tahu bahwa setiap gambaran kehidupan timbul dari kehidupan yang serupa dan berketurunan terjadi dalam bermacam-macam bentuk. Ketiga, mempersiapkan anak untuk menghadapi perubahan-perubahan yang akan terjadi akibat pertumbuhannya, Keempat, menjadikan anak merasa bangga dengan jenis kelamin yang ia di dalam kelompok itu. Di samping itu memandang lawan jenis dengan penghargaan terhadap kelebihan dan keistimewaan. 
Menciptakan perasaan bahwa masalah seks adalah salah satu sisi positif konstruktif dan terhormat dalam kehidupan manusia. Dalam pendidikan seks tidak ada satu metoda yang dibuat dan dilaksanakan lalu segalanya telah selesai, akan tetapi ia adalah proses yang sambung menyambung dan terus menerus. Oleh karena itu makan cara bapak atau guru menghadapi suatu suasana tidak begitu penting, yang penting adalah hubungn baik antara orang tua atau guru dengan anak, yang kadang-kadang bersalah namun barangkali itulah obatnya. Dengan demikian, menurut Felicia, bahwa pendidikan seksual pada siswa tidak sistematis, bersifat situasional, belum dapat dievaluasi keefektifannya dan belum merata kepada seluruh siswa. (Felicia and S. Pandia 2017)

Pendidikan seks tidak akan menimbulkan ingin tahu yang buruk pada anak-anak, bahkan anak-anak yang mengetahui fakta-fakta tentang seks dan mereka yakin bahwa orang tua dan guru-gurunya mau berbicara tentang hal tersebut secara terbuka, maka perhatiannya terhadap masalah seks akan berkurang, selama mereka mendapat jawaban yang memadai terhadap pertanyaan. Wajar jika anak-anak selalu minta penjelasan agar mereka mengetahui, dan ada baiknya mereka berbuat demikian. Dengan demikian, orang tua, atau guru baiknya menyiapkan bekal wawasan yang luas sehingga mampu menjawab pertanyaan dengan mantab dan meyakinkan anak-anak. Sehingga anak-anak tidak ragu, gagal paham, bahkan dampak perilaku yang salah.

Perhatikan bahwa sesungguhnya pendidikan seks yang mantab tidak akan menimbulkan goncangan apapun, dan tidak akan membawa pikiran yang berhubungan dengan segi-segi seks. Maka anak-anak khususnya yang masih kecil menerima informasi yang berhubungan dengan masalah tersebut secara tenang, yang mengagumkan apabila orang-orang dewasa membekali mereka dengan informasi-informasi tentang itu secara tenang dan terbuka. Dan tidaklah aneh jika informasi tersebut sedikit mengalami perubahan dan goncangan dalam pikiran ank kecil. Dan apabila anak berumur tidak lebih dari empat tahun untuk pertama kali mendengar penjelasan tentang ban mobil pecah, diperkirakan ia tidak akan mengerti. Begitu juga anak yang berumur lima tahun tidak akan mengerti bagaimana bayi keluar dari perut ibunya. Akan tetapi informasi-informasi yang benar tentang masalah masalah-masalah seks akan melempengkan jalan untk memahami fungsifungsi seks secara sehat. Sedangkan pengalihan jawaban semuanya akan membawa kepada pengertian yang salah tentang fungsi seks untuk selamanya. 
Pendidikan seks mengurangkan keinginan untuk melakukan percobaan, maka percobaan dalam masalah seks, adalah sebagian besar timbul dari perhatian tentang kelahiran karena kurang pengertian. Pengertian akan masalah-masalah seks juga membantu anak untuk menerima aturan-aturan sosial yang diharuskan terhadap perilaku sosial. Maka pendidikan seks membantu si kecil untuk memahami sebabsebab yang membawa kepada adanya berbagai larangan-larangan sosial yang bermacam-macam, dan terbentuknya nilai-nilai yang dipegangnya sebagai petunjuk dalam perilaku seksual, dengan demikian, secara dini ia lebih mampu mengatasi dorongan-dorongan seks ketika ia telah sampai pada masa matang.

\section{SIMPULAN}

Pendidikan seks amat penting diajarkan sejak dini. Ini tentunya disertai dengan memasukkan nilai-nilai positif dalam pengajaran bagi anak-anak. Berbagaii pertanyaan yang mengandung kuriositas yang berkaitan dengan seks sudah sepatutnya dijelaskan oleh orang tua, keluarga dan guru dengan tepat dan jelas. Tidak perlu memberi analogi yang salah sehingga memberikan kesan dan anggapan yang salah di usia mendatang bagi anak. Sesungguhnya pendidikan seks yang mantab akan memunculkan pamahaman yang mantab pula bagi anak. Dan inii sebagai bekal bagi mereka agar tidak terperangkap pada kesalahan dan permasalahan seks di kemudian hari. 


\section{DAFTAR PUSTAKA}

Andrianto, Tuhaha Taufiq, Mengembangkan Karakter sukses anak di Era Cyber, Yogyakarta. 2013.

Aji, Nhimas Ajeng Putri, Tritjahjo Danny Soesilo, and Yustinus Windrawanto. 2018. "Pelaksanaan Pendidikan Seks Pada Anak Usia Dini Oleh Orang Tua Dan Guru Di Tk Pamekar Budi Demak." Penguatan Pendidikan Karakter Pada Siswa Dalam Menghadapi Tantangan Global(0291):111-17.

Anggraini, Trinita, Riswandi, and Sofia Ari. 2017. "Pendidikan Seksual Anak Usia Dini: Aku Dan Diriku." Jurnal Pendidikan Anak 3(2):1-14.

Cresswell, J.W., 2008, Research Design: Qualitative, Quantitative, and Mixed Methods Approaches. Third Edition, Sage Publication, Cd alifornia. Terjemahan A. Fawaid., 2010, Research Design: Pendekatan Kualitatif, Kuantitatif, dan Mixed.

Felicia, Juliette Pepita, and Weny Savitry S. Pandia. 2017. "Persepsi Guru Tki Terhadap Pendidikan Seksual Anak Usia Dini Berdasarkan Health-Belief Model." Jurnal Pendidikan Anak 6(1):71-82.

Halstead, J. Mark \& Michael Reiss, 2004, Nilai Pendidikan Seks bagi Remaja, Yogyakarta.

Laily Hidayati, 2016, Stop ! Push-Parenting: Shoot Parent's ambition as Kind of Psichological Abuse in Parenting" diakses pada 042016.

Peter Gordon 2009, Sexuality Education and The Prevention of Sexual Violence accessed on January $30^{\text {th }} 2017$,

Ratnasari, Risa Fitri, and M. Alias. 2016. "Pentingnya Pendidikan Seks Untuk Anak Usia Dini." Jurnal Tarbawi Khatulistiwa 2(2):55-59.

Rista Fitri Ratnasari, Pentingnya Pendidikan Seks untuk Anak Usia Dini diakses pada 2017

Roqib, Moh. 1970. "Pendidikan Seks Pada Anak Usia Dini." INSANIA: Jurnal Pemikiran Alternatif Kependidikan 13(2):271-86.

Ruíz, Arróliga Araica; $\quad 2015 . \quad$ Blandón. No

主観的健康感を中心とした在宅高齢者における

健康関連指標に関する共分散構造分析Title." 3(2):54-67.

Rusty Justicia, 2015, Program Underwear Rulesu untuk Mencegah Kekerasan Seksual pada Anak Usia Dini pada Jurnal Pendidikan Usia dini Vol. 9, Ed. 2.

Solihin. 2015. "Pendidikan Seks Untuk Anak Usia Dini ( Studi Kasus Di TK Bina Anaprasa Melati Jakarta Pusat )." JURNAL JPSD (Jurnal Pendidikan Sekolah Dasar) (1):56-74.

Sugiyono, 2011, Metode Penelitian Kuantitatif, Kualitatif dan R\&D, $11^{\text {th }}$ Edition, Alfabeta, Bandung.

Sumiyati, 2009, 'Indonesian Journal of Islamic Early Childhood Education. 